\title{
Effect of Work-Life Balance, Job Demand, Job Insecurity on Employee Performance at PT Jaya Lautan Global with Employee Well-Being as a Mediation Variable
}

\author{
Christina Kurnia and Aslam Mei Nur Widigdo
}

\section{ABSTRACT}

Employee performance remains a challenge for companies because of the increasingly competitive level of competition. Organizations are increasingly required to focus on Human Resource Management (HRM) to improve organizational sustainability. Achieving organizational sustainability becomes unrealistic without employee participation and commitment. This study aims to analyze the effect of work-life balance, job demands, job insecurity on employee performance with employee wellbeing as a mediating variable. The research method used is explanatory quantitative with SEM-PLS. The sample in this study were 100 employees of PT Jaya Lautan Global. The sampling technique used in this research is saturated sampling (census). The results showed that Work-Life Balance and Job Demands had a positive and significant effect on Employee WellBeing. Job Insecurity has a negative and significant effect on Employee Well-Being. Work-life balance has a positive and significant effect on employee performance. Job Demands have a negative and significant effect on employee performance, while Job Insecurity has a negative and insignificant effect on employee performance. Employee well-being has a positive and significant effect on employee performance. The results of the mediation show that employee well-being can partially mediate the effect of work-life balance and job insecurity on employee performance, while employee well-being can fully mediate the effect of job demands on employee performance.

Keywords: Employee Performance, Employee Well-Being, Job Demands, Job Inscecurity, Work-Life Balance.

Submitted : June 21, 2021

Published : September 24, 2021

ISSN: 2507-1076

DOI: $10.24018 /$ ejbmr.2021.6.5.948

\section{Christina Kurnia*}

Magister Management, Mercu Buana

University, Jakarta, Indonesia.

(e-mail: audreychristina46@gmail.com)

Aslam Mei Nur Widigdo

Magister Management, Mercu Buana

University, Jakarta, Indonesia.

*Corresponding Author

\section{INTRODUCTION}

Employee performance is one of the most fundamental challenges for companies because of the increasingly competitive level of competition and is related to the survival of the company. The sustainability of high-level performance in the cargo and document management services industry (forwarding) is currently considered an important pathway to be maintained in the long term.

In the modern era, export-import business activities play an important role in the economy of a country [1]. As support for this business, freight companies and EMKL (Sea Ship Expedition) play an important role. One of the forwarding service industries is PT Jaya Lautan Global (JLG), which is engaged in International Freight Forwarding \& Project Logistic Services.

This company has an important role in the growth of cargo shipping services, especially in transportation in Indonesia since its establishment in 2015. This company focuses on handling cargo projects ranging from door to door, door to port, port to port, handling customs/exportimport documents, trucks, warehouses, ship charters for cargo that is quite large in volume. In handling imported cargo, PT Jaya Lautan Global manages the release and documents of goods in containers from ships at the port and forwarded to storage, namely warehouses, the company distributes goods to consignees after all documents have been completed and vice versa for cargo exports prepares a fleet to pick up cargo at the shipper's warehouse then takes it to the port accompanied by the arrangement of documents at customs until the cargo finally arrives to wait for the berth to be loaded [1].

Complex business processes that require precision are ideally aligned with the quality of the company's human resources. In the organizational context, employees are seen as important matter in determining organizational sustainability [2]. Organizations are increasingly required to focus on Human Resource Management (HRM) to improve organizational sustainability. Achieving organizational sustainability becomes unrealistic without employee participation and commitment.

In fact, based on the company's performance data for 2017-2019, the company's performance fluctuated. As presented in Table 1 below.

Based on Table I indicates there are problems related to employee performance. Supported by the results of Key Performance Indicators (KPI) indicating a decrease in employee performance as presented in Table II below. 
TABLE I: FINANCIAL STATEMENTS OF PROFIT/LOSS OF PT JAYA LAUTAN GLOBAL FOR THE PERIOD OF 2017 TO 2019

\begin{tabular}{cc}
\hline Year & Profit/Loss (in rupiah) \\
\hline 2017 (Profit) & Rp 18.950.722.936,- \\
2018 (Profit) & Rp 8.979.520.950,- \\
2019 (Loss) & (Rp 10.450.315.158,04) \\
\hline Source: PT Jaya Lautan Global (JLG) (2020).
\end{tabular}

TABLE II: Key PERFoRMANCE INDICATOR (KPI) EMPLOYEE OF PT JAYA LAUTAN GLOBAL

\begin{tabular}{cc}
\multicolumn{2}{c}{ LAUTAN GLOBAL } \\
\hline Year & $\begin{array}{c}\text { Key Performance Indicator }(\mathrm{KPI}) \\
(\%)\end{array}$ \\
\hline 2017 & 80,05 \\
2018 & 74,92 \\
2019 & 74,55 \\
\hline
\end{tabular}

Source: PT Jaya Lautan Global, Processed.

Based on Table II shows that the KPI value of employees in 2017 was $80.05 \%$, in 2018 it fell to $74.92 \%$ and in 2019 it fell again to $74.55 \%$.

In theory, there are three main factors that affect employee performance, namely individual abilities, including talents, interests, and personality characteristics of employees [3]. Organizational factors include training and development, equipment and technology, performance standards, and management and co-workers. Effort expended includes motivation, job design, work ethic, and the level of employee turnover. Factors that affect employee performance include internal factors, among others: intellectual ability, work discipline, job satisfaction and employee motivation. External factors include: leadership style, work environment, compensation and management system in the company [4].

There are several studies that find factors that affect employee performance, including: work-life balance [2], [5], [6], job demands [7]-[9], job insecurity [10], ability, job satisfaction [11], organizational virtuousness [12], and employee well-being [12]-[14].

The results of a survey conducted on 35 employees of PT Jaya Lautan Global by proposing several factors related to employee performance including work-life balance, organizational virtuousness, work environment, compensation, job satisfaction, job demand, job insecurity, employee well-being obtained the following results.

TABLE III: Results of A PRE SURVEY OF PERFORMANCE OF PT JAYA LAUTAN GLOBAL EMPLOYEES

\begin{tabular}{cccc}
\hline No. & $\begin{array}{c}\text { Indication of Factors Related } \\
\text { to Employee Performance }\end{array}$ & Freq & $\%$ \\
\hline 1 & Work-life balance & 8 & 22,9 \\
2 & Organizational virtuousness & 2 & 5,7 \\
3 & Work motivation & 2 & 5,7 \\
4 & Work environment & 2 & 5,7 \\
5 & Compensation & 3 & 8,6 \\
6 & Work satisfaction & 2 & 5,7 \\
7 & Job demand & 6 & 17,1 \\
8 & Job insecurity & 4 & 11,4 \\
9 & Employee well-being & 6 & 17,1 \\
& Total & 35 & 100 \\
\hline
\end{tabular}

Source: May 2020 Survey.

Based on the results of the pre-survey in Table III it is known that from a total of 35 employees surveyed there are four highest factors perceived by employees, namely worklife balance who answered 8 people $(22.9 \%)$, job demand as many as 6 people $(17.1 \%)$, job insecurity as many as 4 people $(11.4 \%)$, and employee well-being as many as 6 people $(17.1 \%)$

Referring to the results of the pre-survey, this study aims to explain the effect of work-life balance, job demand, and job insecurity on employee well-being and employee performance. In addition, this study also explains the mediating role of employee well-being on the effect of work-life balance, job demand, and job insecurity on employee performance at PT. Jaya Lautan Global.

\section{LITERATURE REVIEW AND HYPOTHESIS DEVELOPMENT}

\section{A. Effect of Work-Life Balance on Employee Well-Being}

When work interferes with the family, work-to-family conflict arises. Organizational efforts to improve employee welfare through the development of work-family policies can help resolve this problem. Work-family policies include work practices that aim to balance work, family and personal demands [5]. Employees who have the ability to balance their functions between their roles in work and nonwork can meet the needs and aspects of their lives so that their welfare can increase. [15]. Work-life imbalance is one of the 13 psychosocial factors found to be associated with low levels of employee well-being [16].

H1: Work-life balance has a positive and significant effect on employee well-being.

\section{B. Effect of Job Demand on Employee Well-Being}

The higher work demands can cause stress, thereby reducing the level of employee welfare. Employees who are exposed to high and prolonged work demands can become psychologically exhausted and alienated from work, which in turn reduces their well-being. The results show that job demands negatively affect the welfare of cruise ship employees [17].

$\mathrm{H} 2$ : Job demand has a negative and significant effect on employee well-being.

\section{The Effect of Job Insecurity on Employee Well-Being}

Uncertainty in the condition of the company can have a negative impact on employees who are still working at the company, namely an increase in workload as a consequence of the delegation of workloads for employees who were previously affected by termination of employment (PHK). Employees will be busy wondering when it will be their turn to be laid off, resulting in feelings of stress, job insecurity and lowering their level of welfare [18]. Job insecurity also causes an employee to have no satisfaction in his life and not feel happy in his life. Job insecurity makes employees think negatively about the future of their work.

H3: Job insecurity has a negative and significant effect on employee well-being.

\section{Effect of Work-Life Balance on Employee Performance}

Among human resource management (HRM) practices, improving work-life balance is considered as one of the HRM practices that greatly contributes to improving employee performance [2]. Achievement of a better worklife balance can yield dividends for employers in terms of having a more motivated, productive, less stressed workforce, increasing productivity, and reducing 
absenteeism. Work-life balance can have an impact on both individuals and organizations [19]. The results of previous studies confirm that work-life balance has a significant positive effect on employee performance [2], [5], [6], [13], [19]-[24].

H4: Work-life balance has a positive and significant effect on employee performance.

\section{E. Effect of Job Demand on Employee Performance}

According to resource conservation theory (COR), various stressful actions (i.e., conflict, dissatisfaction, and withdrawal behavior) occur when resources are threatened or lost or when individuals invest resources and do not obtain the expected benefits. Thus, job demands can lead to negative work attitudes resulting in decreased performance [8]. The results of the study prove that job demand has a significant effect on employee performance [9].

H5: Job demand has a negative and significant effect on employee performance.

\section{F. The Effect of Job Insecurity on Employee Performance}

Companies should pay more attention to maintaining social exchange relationships with employees who have lower cultural values [7]. Job insecurity is a barrier that leads to negative behavioral consequences in the workplace [25]. Employees with high levels of job insecurity generally perform worse. The similarity of research result [26], that work has a significant influence on employee performance. Similar results are shown [25], that job insecurity has a significant effect on employee performance.

H6: Job insecurity has a negative and significant effect on employee performance.

\section{G. The Effect of Employee Well-Being on Employee Performance}

Employee well-being is likely to introduce changes in the organizational climate that can result in positive employee outcomes, including increased employee performance [14]. Employee well-being, i.e. psychological, physical and social well-being, is positively related to employee performance [14]. Research [25] found that subjective well-being had a significant effect on employee performance. Meanwhile, research [27] found that there was a positive and significant influence between psychological well-being on employee performance.

H7: Employee well-being has a positive and significant effect on employee performance.

\section{H. Employee Well-Being Mediates the Effect of Work- Life Balance on Employee Performance}

The influence of work environment, employee personality and psychological climate in the workplace on job outcomes, such as employee performance, is often measured through happiness-related constructs such as job satisfaction, affective commitment, and mood at work. The results of the study [5] found that employee well-being mediates the effect of work-family balance on employee performance. Work-family policies include working time flexibility, paid sabbatical leave, and providing flexibility in the work location (flexible place), can improve employee performance because it can provide employee welfare.

H8: Work-life balance has a positive and significant effect on employee performance through employee wellbeing.

\section{Employee Well-Being Mediates the Effect of Job Demands on Employee Performance}

Employees who experience high and prolonged work demands can become very psychologically tired and alienated from their work, which in turn reduces their wellbeing, resulting in decreased performance [17]. This is because employee welfare provides stress-free conditions to be more creative and ultimately improve employee performance [13]. Therefore, the employee has to work harder to keep the job even if the employer fails to fulfill his reciprocal obligations (challenging the demands of the job in exchange for a secure job). Therefore, employee welfare is very important to mediate the high demands of work so that it can improve its performance.

H9: Job demand has a positive and significant effect on employee performance through employee well-being.

\section{J. Employee Well-Being Mediates the Effect of Job Insecurity on Employee Performance}

In conditions of job insecurity, employees experience lower levels of well-being because they face the possibility of losing their most important work-related resources, which can meet their needs, resulting in decreased performance. The results of the study [25] prove that job insecurity has a significant negative effect on employee performance through a decrease in employee welfare.

H10: Job insecurity has a negative and significant effect on employee performance through employee well-being.

\section{Research MEthodology}

This study uses a quantitative approach with a descriptive type of research. A quantitative approach is used because the data used in this study will be processed using statistics. While descriptive research is investigating circumstances, conditions or other things by not changing, adding, or manipulating the object or area of research. The researcher only takes pictures of what happens to the object or area under study, then describes what happened in the form of a research report in a straightforward manner, as it is [28]. The population in the study were all employees of PT Jaya Lautan Global. The total population of all employees is 100 people. The sampling technique used is census, the entire population is sampled. Thus, the sample used in this study were 100 respondents from PT Jaya Lautan Global employees. The data collection procedure used in this study consisted of a questionnaire and documentation. The data analysis technique of this research uses the. structural equation model (SEM-PLS).

\section{RESEARCH RESULT AND DISCUSSION}

The results of the descriptive analysis on each research variable are shown in Table IV below.

The mean value indicated by the work-life balance dimension ranges from 4.17 to 4.37 . The highest mean value is found in the Tension dimension which has a mean value of 4.40. This means that employees can still focus on work 
despite family problems, employees continue to work despite family/personal problems, and high work demands do not make their personal life a mess.

TABLE IV: DESCRIPTIVE ANALYSIS OF RESEARCH VARIABLES

\begin{tabular}{ccc}
\hline Variable & Dimension & Mean \\
\hline \multirow{3}{*}{ Work-life balance } & Time (X1.1) & 4.17 \\
(X1) & Tension (X1.2) & 4.40 \\
& Energy (X1.3) & 4.30 \\
& Behavior (X1.4) & 4.37 \\
\hline \multirow{2}{*}{ Job Demands (X2) } & Qualitative demands (X2.1) & 2.25 \\
& Quantitative demands (X2.2) & 2.31 \\
\multirow{2}{*}{ Job Insecurity (X3) } & Organizational demands (X2.3) & 2.87 \\
\hline \multirow{2}{*}{ Employee Well-Being } & Cognitive (X3.1) & 2.85 \\
(Y1) & Affective (X3.2) & 2.86 \\
\hline \multirow{2}{*}{ Employee } & Economical (Y1.1) & 4.23 \\
Performance (Y2) & Facilities (Y1.2) & 4.20 \\
& Service (Y1.3) & 4.05 \\
\hline & Quality of work (Y2.1) & 4.21 \\
& Quantity of work (Y2.2) & 4.14 \\
& Co-working time (Y2.3) & 4.20 \\
& & 4.17 \\
\hline
\end{tabular}

The mean value indicated by the job demands dimension ranges from 2.25 to 2.87 . The lowest mean value is in the qualitative demands dimension with a mean value of 2.25 . This means that the work felt by employees requires high emotions, a lot of attention and high concentration, and excellent physical.

The mean value indicated by the job insecurity dimension ranges from 2.85 to 2.86 . The lowest mean value is found in the cognitive dimension with a mean value of 2.85 . These results explain that some employees feel that their work is not important, are nervous about company rules, are helpless with work procedures and job security, are anxious about becoming unemployed, and are concerned about their fate in the company. But some other employees do not feel the cognitive aspect.

The mean value indicated by the dimension of employee well-being ranges from 4.05 to 4.23 . The dimension of Employee Well-Being which has the highest mean value is found in the economic dimension with a mean value of 4.23. This means that most employees feel that the pension provided by the company is in accordance with the period of service, the provision of THR exceeds what is expected, the provision of food allowance really helps them to work better, the provision of transportation money is very supportive of their attendance on time, and the treatment money given. The company is very helpful in selfmedicating.

The mean value indicated by the dimensions of employee performance ranges from 4.14 to 4.21 . The dimension of the employee performance variable which has the highest mean value is found in the work quality dimension which has a mean value of 4.21. This means that most employees perceive that they have worked very calculatingly, carefully, and thoroughly, have knowledge that is very appropriate to their work, and are very aware of the importance of accuracy in completing work.

The results of the research hypothesis test using SEM PLS which pay attention to the value of the inner model shown.

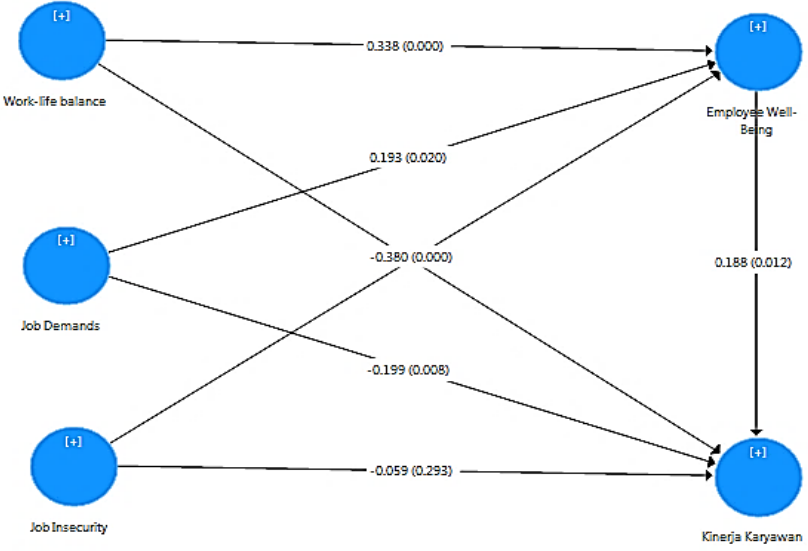

Fig. 1. Results of the Structural Model (Inner Model).

TABLE V: HyPOTHESIS TEST RESULTS FOR DIRECT EFFECT

\begin{tabular}{|c|c|c|c|}
\hline Construct & $\begin{array}{l}\text { Original } \\
\text { Sample }\end{array}$ & $\mathrm{P}$-value & Information \\
\hline $\begin{array}{l}\text { Work-Life Balance } \\
\text { Employee Well-Being }\end{array}$ & 0.338 & 0.000 & $\begin{array}{l}\text { Positive, } \\
\text { Significant }\end{array}$ \\
\hline $\begin{array}{l}\text { Job Demands } \rightarrow \text { Employee } \\
\text { Well-Being }\end{array}$ & 0.193 & 0.020 & $\begin{array}{l}\text { Positive, } \\
\text { Significant }\end{array}$ \\
\hline $\begin{array}{l}\text { Job Insecurity -> Employee } \\
\text { Well-Being }\end{array}$ & -0.380 & 0.000 & $\begin{array}{l}\text { Negative, } \\
\text { Significant }\end{array}$ \\
\hline $\begin{array}{l}\text { Work-Life Balance } \quad \rightarrow \\
\text { Employee Performance }\end{array}$ & 0.198 & 0.031 & $\begin{array}{l}\text { Positive, } \\
\text { Significant }\end{array}$ \\
\hline $\begin{array}{l}\text { Job Demands }->\text { Employee } \\
\text { Performance }\end{array}$ & -0.199 & 0.008 & $\begin{array}{l}\text { Negative, } \\
\text { Significant }\end{array}$ \\
\hline $\begin{array}{l}\text { Job Insecurity } \rightarrow \text { Employee } \\
\text { Performance }\end{array}$ & -0.059 & 0.293 & $\begin{array}{l}\text { Negative, Not } \\
\text { Significant }\end{array}$ \\
\hline $\begin{array}{l}\text { Employee Well-Being } \quad-> \\
\text { Employee Performance }\end{array}$ & 0.188 & 0.012 & $\begin{array}{l}\text { Positive, } \\
\text { Significant }\end{array}$ \\
\hline
\end{tabular}

Work-life balance has a significant positive effect on employee well-being, which is indicated by the original sample value (path coefficient) of 0.338 (positive) with a $\mathrm{p}$ value of 0.000 . These results explain that employees who are able to balance their work and personal life significantly can feel cheerful and excited, calm and relaxed, active and energetic, fresh and their daily life is filled with interesting things that improve their welfare.

Job demands have a significant positive effect on employee well-being, as indicated by the original sample value (path coefficient) of 0.193 (positive) with a $p$ value of 0.020 . These results explain that employees with high work demands actually become the motivation for every employee to want to work. Employee well-being is the end point of all the energy and effort that is made in fulfilling their life's needs.

Job insecurity has a significant negative effect on employee well-being, which is indicated by the original sample value (path coefficient) of -0.380 (negative) with a $p$ value of 0.000 . These results explain that the condition of job insecurity experienced by employees has a negative impact on both themselves and the organization. For themselves, employees can feel the decline in their welfare.

Work-life balance has a significant positive effect on employee performance, as indicated by the original sample value (path coefficient) of 0.198 (positive) with a $\mathrm{p}$ value of 0.031. These results explain that the work-life balance program implemented by the company can create morale for employees in carrying out their duties and obligations to the company. 
Job demands have a significant negative effect on employee performance, as indicated by the original sample value (path coefficient) of -0.199 (negative) with a $\mathrm{p}$ value of 0.008 . These results explain that the higher Job Demands will decrease employee performance. Employees who are exposed to high job demands can become very tired psychologically and psychologically, which leads to decreased performance.

Job insecurity has an insignificant negative effect on employee performance, which is indicated by the original sample value (path coefficient) of -0.059 (negative) with a $\mathrm{p}$ value of 0.293. These results explain that working conditions are safe or not, employees will still show good performance.

Employee well-being has a significant positive effect on employee performance, which is indicated by the original sample value (path coefficient) of 0.188 (positive) with a $\mathrm{p}$ value of 0.012 . These results explain that companies that pay attention to and improve employee welfare programs (economical, facilitative, and service) can have an influence on employee performance.

TABLE VI: HYPOTHESIS TEST RESULTS FOR INDIRECT EFFECT

\begin{tabular}{|c|c|c|c|}
\hline Construct & $\begin{array}{c}\text { Path } \\
\text { Coefficient }\end{array}$ & P-value & Information \\
\hline $\begin{array}{l}\text { Work-Life } \quad \text { Balance -> } \\
\text { Employee } \quad \text { Well-Being-> } \\
\text { Kinerja Karyawan }\end{array}$ & 0.063 & 0.039 & $\begin{array}{c}\text { Positive, } \\
\text { Significant }\end{array}$ \\
\hline $\begin{array}{l}\text { Job Demands -> Employee } \\
\text { Well-Being-> } \\
\text { Karyawan }\end{array}$ & 0.036 & 0.070 & $\begin{array}{c}\text { Positive, Not } \\
\text { Significant }\end{array}$ \\
\hline $\begin{array}{lr}\text { Job Insecurity -> Employee } \\
\text { Well-Being-> } & \text { Kinerja } \\
\text { Karyawan } & \\
\end{array}$ & -0.071 & 0.037 & $\begin{array}{l}\text { Negative, } \\
\text { Significant }\end{array}$ \\
\hline
\end{tabular}

On the indirect effect, the results of the hypothesis test show that employee well-being can partially mediate the effect of work-life balance on employee performance, which is indicated by the path coefficient value of 0.063 and the $p$ value of 0.039 . These results explain that a high workpersonal balance further enhances performance if it involves a high work welfare program.

The results of the subsequent indirect effect hypothesis test show that employee well-being is unable to mediate the effect of job demands on employee performance. If you look at the results of the direct effect, it is known that job demands have a significant negative effect on employee performance. These results explain that higher job demands will reduce employee performance but not when going through employee well-being.

The results of the indirect hypothesis test further indicate that employee well-being is a partial mediator between the effect of job insecurity on employee performance, which is indicated by the path coefficient value of -0.071 and the $p$ value of 0.037 . These results explain that the greater the insecurity felt by employees during work will reduce employee well-being and will reduce employee performance.

\section{CONClusions}

The results of the study explain that work-life balance and job demand have a significant positive effect on employee well-being. In addition, job insecurity also has a significant negative effect on employee well-being. These results explain that work-life balance, job demands, and job insecurity have a role to provide overall welfare for employees.

The results also explain that work-life balance and employee well-being have a significant positive effect on employee performance, while job demands have a significant negative effect on employee performance and job insecurity has no significant effect on performance. The family felt by employees and the better welfare of employees will encourage employees to show better performance. In addition, higher work demands actually have a negative impact on performance. On the other hand, employee performance is not determined by job insecurity.

In the indirect effect, it is known that employee wellbeing does not have a mediating role on the effect of job demands on employee performance, but employee wellbeing has a mediating role on the effect of work-life balance and job insecurity on employee performance.

Based on the conclusions that have been explained, the suggestions that can be put forward are: (1) the company, namely PT JLG can improve work-life balance programs such as family-friendly benefits including resources on parent and child care, care, health and employee welfare , and relocation and others, which are needed by employees to balance life and work, which include flextime, job sharing, telecommunicating and others, so that it can have an impact on employee performance; (2) re-evaluate the task procedures, work pressures, failures experienced by employees, employee responsibilities, self-control if changes occur; (3) reviewing employee welfare programs, especially economic benefits related to money, such as salaries and benefits; (4) reviewing regulatory and policy issues, workplace bullying and employee role and personal conflicts.

In practice, this research has limitations, including: (1) The object of this research is only at PT. Jaya Lautan Global, not on all existing forwarding companies; (2) This study only limits to three exogenous variables, namely work-life balance, job demand, job insecurity and two endogenous variables, namely employee well-being and employee performance; (3) Performance behavior is carried out by self-assessment, this can lead to bias because the tendency of self-assessment reports does not provide an overview of the actual respondent's condition, therefore the involvement of other parties is needed to assess the behavior so that the results are balanced.

\section{REFERENCES}

[1] H. Najib, C. Kurnia, and E. Rimawan, "Analysis of Operational Management of Forwarder Service Companies PT . Jaya Lautal Global," Int. J. Innov. Sci. Res. Technol., vol. 4, no. 1, pp. 212-2018, 2019.

[2] N. Thevanes and T. Mangaleswaran, "Relationship between WorkLife Balance and Job Performance of Employees," IOSR J. Bus. Manag., vol. 20, no. 5, pp. 11-16, 2018.

[3] R. L. Mathis and J. H. Jackson, Human Resource Management. South-Western: Cengage Learning, 2013.

[4] S. A. Nitisemito, Manajemen Personalia (Manajemen Sumber Daya Manusia). Jakarta: Ghalia Indonesia, 2014.

[5] J. A. Medina-Garrido, J. M. Biedma-Ferrer, and A. R. RamosRodríguez, "Relationship between work-family balance, employee 
well-being and job performance," Acad. Rev. Latinoam. Adm., vol. 30, no. 1, pp. 40-58, 2017.

[6] K. adnan Bataineh, "Impact of Work-Life Balance, Happiness at Work, on Employee Performance," Int. Bus. Res., vol. 12, no. 2, p. 99, 2019.

[7] C. Lu, D. Y. Du, X. M. Xu, and R. F. Zhang, "Revisiting the relationship between job demands and job performance: The effects of job security and traditionality," J. Occup. Organ. Psychol., vol. 90, no. 1, pp. 28-50, 2016.

[8] C. Lu, B. Wang, O. Siu, L. Lu, and D. Du, "Work-home interference and work values in Greater China," J. Manag. Psychol., vol. 30, no. 7, pp. 801-814, 2015.

[9] L. Y. Y. Siahaan, H. U. Anisah, and R. Rahmawati, "Pengaruh Job Demand Terhadap Kinerja Anggota Polri Dengan Variabel Stres dan Burnout Sebagai Variabel Mediasi," J. Wawasan Manaj., vol. 7, no. 2, pp. 184-201, 2019.

[10] M. Darvishmotevali and F. Ali, "Job insecurity, subjective well-being and job performance: The moderating role of psychological capital," Int. J. Hosp. Manag., vol. 87, no. February 2019, p. 102462, 2020.

[11] R. Sidik, "Pengaruh Kemampuan, Work Life Balance, Kepuasan Kerja Terhadap Kinerja Karyawan Pada Karyawan," Yos Soedarso Econ. J., vol. 1, no. April, pp. 20-28, 2019.

[12] R. Magnier-Watanabe, T. Uchida, P. Orsini, and C. Benton, "Organizational virtuousness and job performance in Japan: does happiness matter?," Int. J. Organ. Anal., vol. 25, no. 4, pp. 628-646, 2017.

[13] S. Haider, S. Jabeen, and J. Ahmad, "Moderated mediation between work life balance and employee job performance: The role of psychological wellbeing and satisfaction with coworkers," J. Work Organ. Psychol., vol. 34, no. 1, pp. 29-37, 2018.

[14] V. Khoreva and H. Wechtler, "HR practices and employee performance: the mediating role of well-being," Empl. Relations, vol. 40 , no. 2, pp. 227-243, 2018.

[15] D. Cintantya and H. Nurtjahjanti, "Hubungan Antara Work-Life Balance Dengan Subjective Well-Being Pada Sopir Taksi Pt. Express Transindo Utama Tbk Di Jakarta," Empati, vol. 7, no. 1, pp. 339-344, 2018.

[16] J. W. Yang, C. Suh, C. K. Lee, and B. C. Son, "The work-life balance and psychosocial well-being of South Korean workers," Ann. Occup. Environ. Med., vol. 30, no. 1, pp. 1-7, 2018.

[17] A. Radic, J. M. Arjona-Fuentes, A. Ariza-Montes, H. Han, and R. Law, "Job demands-job resources (JD-R) model, work engagement, and well-being of cruise ship employees," Int. J. Hosp. Manag., vol. 88, no. October 2019, p. 102518, 2020.

[18] T. R. Rizky and N. Sadida, "Hubungan antara Job Insecurity dan Employee Well Being pada Karyawan yang Bekerja di Perusahaan yang Menerapkan PHK di DKI Jakarta," J. Empati, vol. 8, no. 1, pp. 329-335, 2019.

[19] M. D. V. S. Mendis and W. A. S. Weerakkody, "The impact of work life balance on employee performance with reference to telecommunication industry in Sri Lanka: a mediation model," Kelaniya J. Hum. Resour. Manag., vol. 12, no. 1, p. 72, 2018.

[20] K. T. Smith, L. M. Smith, and T. R. Brower, "How Work-Life Balance, Job Performance, and Ethics Connect: Perspectives of Current and Future Accountants," Res. Prof. Responsib. Ethics Account., vol. 20, pp. 219-238, 2016.

[21] Asima and L. Nilawati, "Pengaruh Work-Life Balance Terhadap Kinerja Karyawan Yang Dimediasi Oleh Komitmen Afektif," Optim. J. Ekon. dan Pembang., vol. 6, no. 1, p. 68, 2016.

[22] I. Saina, R. Pio, and W. Rumawas, "Pengaruh Worklife Balance Dan Kompensasi Terhadap Kinerja Karyawan Pada Pt Pln (Persero) Wilayah Suluttenggo Area Manado," J. Adm. Bisnis UNSRAT, vol. 4, no. 3, pp. 1-9, 2016.

[23] C. Mulanya and A. Kagiri, "Effect of work life balance on employee performance in constitutional commissions in kenya. A case of commission on revenue allocation," Strateg. J. Bus. Chang. Manag., vol. 5, no. 4, pp. 1448-1466, 2018.

[24] W. O. Nurhasanah M, L. O. Kalimin, and D. T. Syaifuddin, "The Effect of Work Life Balance on Job Satisfaction and Female Employee Performance in Commercial Bank in Kendari City," vol. 21 , no. 5, pp. 1-7, 2019.

[25] M. Darvishmotevali, H. Arasli, and H. Kilic, "Effect of job insecurity on frontline employee's performance: Looking through the lens of psychological strains and leverages," Int. J. Contemp. Hosp. Manag., vol. 29, no. 6, pp. 1724-1744, 2017.

[26] N. L. Nikmah, Murgianto, and R. Nugroho, "Influence Of Job Insecurity, Work Motivation, Organizational Commitments And Work Satisfaction As Intervening Variables To Employee Performance (Case Study of PT Semar Beton Perkasa, Tuban Regency)," Arch. Bus. Res., vol. 7, no. 9, pp. 192-202, 2019.
[27] D. Wahyuningsih and N. A. Wulansari, "The Impact of Psychological Capital On Nurse's Performance: The Mediating Role of Psychological Well-Being and Work-Family Conflict," Manag. Anal. J., vol. 5, no. 4, pp. 325-338, 2016.

[28] S. Arikunto, Prosedur Penelitian Suatu Pendekatan Praktik. Jakarta: Rineka Cipta, 2016. 